\title{
New Perspectives of the Digitized Correspondence of Constantijn Huygens (1596-1687)
}

\author{
Ineke Huysman and Ad LeerintVeld \\ Huygens Institute of Dutch History and National Library of the Netherlands, \\ The Hague, NL
}

The prominent Dutch poet and secretary to Frederick Henry, Constantijn Huygens (1596-1687), was a true homo universalis. He was also a diplomat, an art connoisseur, a bibliophile, collector, musician, and a scholar. Mainly by means of his correspondence, he maintained a vast network of contacts reaching 'everybody who mattered' in the Dutch Golden Age. It is estimated that Huygens wrote and received more than 100 ooo letters; of these only 10 ooo have survived. In the early twentieth century, Huygens's correspondence was published by J.A. Worp. While Worp's work was exemplary, his editorial principles and practices fail to meet today's current scholarly standards. For example, Worp sometimes published abstracts of letters, rather than the letters themselves. He also selectively omitted letters that he deemed 'unimportant'. Several years ago the Huygens Institute of Dutch History began to create a new digital edition of Huygens's letters. This online edition of Huygens's correspondence reveals new perspectives on Huygens and on his work and writing. In addition to the newly discovered letters that now have been published, the digital edition also facilitates research on Huygens's varied use of language in letters to people, depending on their social strata. New analysis of his letters also grants insights into how Huygens communicated with the women of his time.

KEYWORDS Constantijn Huygens, correspondence, digitization, letters, Dutch Golden Age, J. A. Worp, Amalia of Solms, Stadtholder Frederick Henry, Béatrix de Cusance, Margaret Cavendish

\section{Introduction}

During his lengthy life of almost 9I years Constantijn Huygens maintained correspondence with princes, stadtholders, courtiers, noble men and women, officers, administrators, poets, painters, architects, and scholars from all over Europe. Everybody who 
'mattered' in the seventeenth century tried to contact Huygens at some time. In examining this correspondence - and by taking into consideration his personal letter exchanges with family and friends as well - one sees the spirit of the entire Dutch Golden Age clearly reflected.

In this contribution we present some new perspectives for the study of Huygens's letters that have become possible thanks to the digitization project that has been

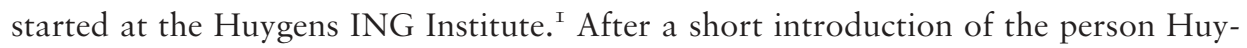
gens, we discuss the principles that J.A. Worp, the editor of Huygens's Briefwisseling followed in his monumental edition. In the second section of this article we provide examples of recently discovered letters and newly found evidence for more precise dates for some letters. The third and final part is devoted to an overview of new perspectives in the study of Huygens's letters by using the digitized sources.

\section{Constantijn Huygens}

From his childhood Constantijn Huygens (Figure I) was well acquainted with envoys, high officials and court members, as his father Christiaan Huygens, in his position as secretary to the Raad van State, had introduced him into his personal and official network. Furthermore, as a youth Constantijn had participated in embassy journeys to Italy and England. He became a prominent poet in Dutch, French, and Latin and he also constructed a library containing publications on the subject of theology, law, literature, and science. Apart from this, Constantijn was a passionate amateurmusician, he composed music and played several instruments himself, and he was also well acquainted with most prominent musicians of his time. Thus, when in 1625 at

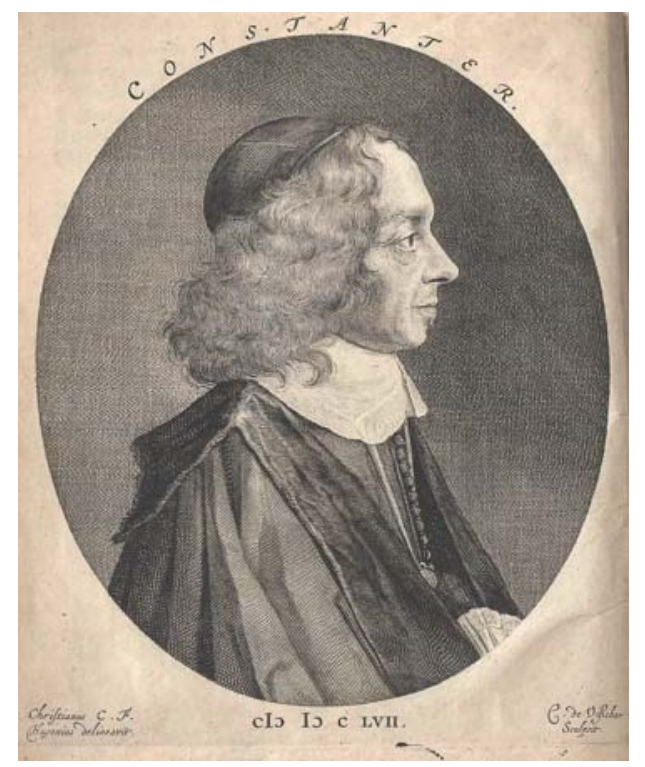

FIGURE 1 Constantijn Huygens, engraving by Cornelis de Visscher.

Koninklijke Bibliotheek, Den Haag, inv. $302 E_{52}$ 
the age of 28, Constantijn became secretary of Stadtholder Frederick Henry, he positioned himself at the centre of political and cultural developments in the Dutch Republic.

In short, Constantijn Huygens was constantly engaged in reinforcing and amplifying his social position and that of his sons. He ensured his career by manifesting himself on different occasions in different roles or qualifications, like those of secretary, diplomat, courtier, poet, art connoisseur, collector, scholar, or musician. In other words, he was a true homo universalis. Purposefully, he utilized his correspondence as a way to present himself as such and to expand his network to higher social layers. $^{2}$

\section{Legacy of letters}

In an autobiographical poem Constantijn wrote at the age of 82 , he mentioned his collection of letters:

Tussen mijn boekenkasten, nakomelingen, zullen jullie een kabinet zien uitpuilen met brieven, en mocht een van jullie ooit denken ze in druk te gaan verspreiden dan ben ik daar zeker niet tegen, moedig het juist aan in de vaste overtuiging dat het vaderland zelf de verzameling op prijs zal stellen.

[Between my bookcases, descendants, you will find a cabinet bulging with letters, and if any of you will ever consider publishing them in print, then I am certainly not opposed. On the contrary, I even encourage it, being convinced that our homeland will appreciate the collection. $]^{3}$

It is clear, therefore, that Constantijn truly wanted his letters to be preserved for posterity. After several generations, Huygens's letters and documents were dispersed and large parts were auctioned. In I823, Dutch King William I obtained the largest part of the collection and donated the letters to several Dutch Institutions. However, an unknown number of letters has unfortunately vanished in private archives. The preserved letters of Constantijn Huygens amount to Io ooo documents, averaging four pages each. They are located in the following archives (ranked by percentage of total):

- Royal Dutch Archives: $37.5 \%$,

- University Library Leiden: $27.4 \%$,

- Koninklijke Bibliotheek, National Library of the Netherlands: $26.6 \%$,

- University Library Amsterdam: 3.2\%,

- British Library: 2.3\%,

- National Dutch Archives: $0.7 \%$,

- Other archives: $2.4 \%$,

- Private archives: number unknown.

At the end of his life, Constantijn estimated that, during his active life as a secretary, he must have written and received more than Ioo 000 letters. As only 10 000 letters have survived, this means that 90 per cent of his correspondence has been lost. 
Huygens himself carefully kept original letters he had received from 'important' persons among his private papers, as he did with his own drafts or copies adressed to them. Still, the preserved correspondence displays some unfortunate gaps. For instance, regarding Constantijn's family, no letters to and from his dearly beloved wife Suzanna van Baerle have been saved. Perhaps Constantijn considered them too personal to preserve for posterity. Other than that, there are no letters from his father Christiaan, and from his sons and vice versa few letters remain. From his musical lady friends Utricia Ogle and Maria de Casembroot no letters have been kept. A large cluster of letters of military officers has disappeared. Likewise, from celebrities as Descartes, Corneille, and Heinsius many more letters must have existed. They probably still do, but these are the kind of letters which will have ended up in private collections. Fortunately however, we still occasionally find new letters.

\section{Edition}

In the early twentieth century the Dutch scholar J.A. Worp published six large volumes containing the entire correspondence of Constantijn Huygens. ${ }^{4}$ In his introduction Worp stated:

Maar eene volledige uitgave der briefwisseling van Constantijn Huygens is niet nodig. In de eerste plaats heeft hij zelf honderden brieven geschreven, die van weinig of van geen belang zijn, daar zij niet veel meer dan beleefdheidsformules bevatten, bedankjes voor het zenden van een boek, galante woordjes aan het adres eener vrouw van de wereld, enz. Maar vooral onder de brieven zijner correspondenten zijn er talloos vele, die van geene beteekenis zijn. De invloedrijke secretaris van den Stadhouder werd door honderden menschen lastig gevallen.

[A complete edition of the correspondence of Constantijn Huygens is not necessary. First of all, Huygens wrote hundreds of letters of no or little importance, as they only contain platitudes, gratitudes for the deliverance of a book, galant words adressed to a woman of the world, etc. But especially amongst his correspondents there are many of no significance whatsoever. The influencial secretary of the Stadtholder was bothered by hundreds of people. $]^{5}$

Unfortunately, the criteria for selection that prevailed at that time differ considerably from our current standards. That means that a substantial amount of material that we find interesting nowadays has been left out, or has only been briefly summarized.

Subsequently, Worp divided the correspondence into four categories of importance, starting with the least important:

I. Letters from officers and individuals in search of higher employment for themselves or their relations, addressing themselves to Huygens because they were hesitant to address themselves directly to the Stadtholder. These were the letters that Worp would not include in his edition. For instance, from the 216 letters from Anthonie van Hilten, secretary of the States of Utrecht, to Constantijn Huygens, Worp only published 69 letters, most of them briefly summarized. ${ }^{6}$ 
This is not the only case where Worp acted so radically; many letters of this genre have been omitted. For the study of patronage systems and gift exchange, however, these kind of letters are most significant and therefore indispensable.

2. Letters from young scholars, poets, and students who wished to ingratiate themselves with Huygens. Worp classified these correspondents under '[...] ene tweede categorie van niet minder lastige vragers' (' [ . . . ] a second category of no less bothersome applicants'). ${ }^{7} \mathrm{He}$ decided to summarize their letters in a few lines, because they '[...] in weerwil van hun onbelangrijken inhoud, iets kunnen bijdragen tot de personengeschiedenis' ('[...] could perhaps, in spite of their unimportant content, add something to the history of persons'). ${ }^{8}$ For example, at the beginning of his career, in I648, Laurens Craen, a young painter from Middelburg in Zeeland, wrote to Huygens to offer his services and to attract his attention. He also provided him with a painting. Though Craen's still life paintings are still highly fashionable, Worp only quoted once sentence from this remarkable letter from Craen to Huygens.

3. Letters that could be of any significance to '[... ] de geschiedenis in den ruimsten zin van het woord' ('[...] to history in the broadest sense'). ${ }^{\text {Io }}$ Of these letters Worp would provide a summary and one or more fragments. For example, many of the letters that Huygens wrote and received on his mission to France, where he tried regain the Princedom of Orange from the French, have been edited in this way. Moreover, many supplements accompanying the original letters have been left out by Worp as well. This is a most unfortunate omission, for any serious research on the history of the negotiations on the Princedom of Orange requires access to the original documents and their annexes.

4. Letters of importance because of the composer or the addressee. Most of the letters of Huygens himself belong to this category. Worp would publish them completely, but he would omit digressions and 'onbelangrijke onderwerpen' ('unimportant subjects'). ${ }^{\text {II }}$ For instance, Huygens's letter of I4 October 1658 to Charles II Stuart, the English king who was at that moment in exile in the Netherlands, is paraphrased by Worp with the following sentence: 'Mijn zoon biedt $\mathrm{u}$ den hierbijgaanden kijker aan; men moet hem op eenigszins andere wijze gebruiken dan andere kijkers, maar men gewent er spoedig aan' ('My son offers you these included binoculars. One should use them in a slightly different way than other binoculars, but one gets used to it very quickly'). ${ }^{\text {I2 }}$ Obviously, this paraphrase is rather simplistic, misleading, and too short. In the original letter father Constantijn presents one of the famous inventions made by his son Christiaan Huygens (I629-95), the prominent mathematician and natural philosopher. This letter is an essential document for the study of life and works of Christiaan Huygens, especially in relation to his first acquaintance with England, where he would become a fellow of the Royal Society in I663. Furthermore, the letter is also relevant for the study of Charles Stuart's life before the Restoration and his network of relations he maintained during his exile. 
Worp's mode of operation is considerably outdated. Many modern editors of historical sources have despaired of the omission of such quantities of possibly important content. Also, the increasing interest in the study of epistolary politeness, conventions, style, and language use requires the correspondence to be complete and preferably integrally searchable as well. ${ }^{13}$

Conclusively, Worp's edition of the Huygens correspondence fails to meet the current standards because of (I) subjective selection criterions, (2) prejudiced and sometimes misleading summarizations, and (3) lack of completeness. Fifteen per cent of the letters at that time available have been excluded and 75 per cent have been summarized or shortened. It is essential that in addition to utilizing the Worp-edition, the researcher reverts to the original source: the Huygens correspondence itself.

\section{New letters}

In this part of our article the importance of Constantijn Huygens's letters will be demonstrated by using examples from various fields of his activity: literature, music, and his professional work as secretary.

For Huygens's career in literature three examples are given. All three deal with letters that, for several reasons, are not to be found as complete or as fully annotated as they should have been in the early twentieth century edition published by J.A. Worp. These letters will be discussed in chronological order, showing how Constantijn became increasingly involved in literary circles.

The first example is a letter composed by Hugo de Groot, the famous lawyer, advocate of Holland, and founder of the Freedom of the seas. On the last day of November I6I4 Hugo Grotius wrote to Christiaan Huygens, Constantijn's father, from Rotterdam, the city he served in the function of pensionaris. He actually replied to a letter in which Christiaan asked the brilliant lawyer some advice on the juridical studies Constantijn was inscribed for at the University of Leiden. Grotius replied and mentioned some titles, but he did more. He also responded to a poem composed by the young Constantijn that the proud father had attached in his letter and wrote:

t' Epithalamium bij u.E. soon gemaeckt op de bruijlloft van d'Heere hautain geeft my hoope Dat hy in de Poesie soo in dije als in andere taelen soude connen excelleren soo hy hem ernstelijck daer toe wilde begeven. De inventie is levendigh: de woorden exquis.

['t Epithalamium made by your Noble Lord's son on the wedding of the Lord Hautain gives me the hope that he could excel in the poetry as well in that language [French] as in other tongues if he seriously prefers to go that path. The invention is vivid, the word exquisite. $]^{\mathrm{I} 4}$

Worp omitted this letter in his edition. He only included letters from and to Constantijn, but not letters in which he was referenced.

The second example is a letter that Worp provided with a wrong date. In I998, the late professor Strengholt of the Free University of Amsterdam republished it with the correct date. ${ }^{15}$ Instead of the year 1625 determined by Worp, this letter dates from 
I62I. In light of this new date, the letter can now be considered the first epistlelary exchanged between Jacob Cats and Huygens. Cats wrote, in Latin, that he was stupefied by the very elegant verses he had recently read and asked the young poet for more verses, if possible, in Dutch. Huygens replied that at the very moment he was working on a poem in Dutch on his birthplace, The Hague, which he called Batava Tempe, dat is 't Voor-hout van sGravenhage (Batava Tempe: That Is The Limeavenue of The Hague). ${ }^{16}$ As a result of the encouragement by Cats, this poem was published in Middelburg in I622, together with 't Costelick Mall (the Costly Folly). An incorrect date in the edition had concealed this information for a long time.

The third example is a letter Huygens wrote to P.C. Hooft in which he asked for a laudatory poem in his first bundle, Otiorum libri sex. Huygens penned this letter in April I625. In his edition Worp includes this letter as number 259. ${ }^{17}$ In a footnote Worp states that the original letter has not been found and that his version is based on an earlier publication. But in 1976, long after Worp's edition had been issued, a new edition of the letters by Hooft was published, compiled by Van Tricht with additional help of other outstanding scholars. ${ }^{18}$ In this source-edition a document is mentioned which is part of the already mentioned large number of letters acquired in I 823 by King William I and transferred to the Dutch Royal Academy. On the conditions of a long term loan, these manuscripts have, since 1937, been preserved at the Koninklijke Bibliotheek, the national library of the Netherlands in The Hague. This letter from Hooft to Huygens bears the signature KA, I7I ac 35. This significant letter reveals the friendship between Hooft and Huygens and marks a crucial period in the printing history of Huygens's Otia. ${ }^{\text {I9 }}$

With regard to Constantijn's musical interests, we here can mention a recent acquisition by the Koninklijke Bibliotheek, the national library of the Netherlands. ${ }^{20}$ At an auction in London this library bought a letter by Gaspar Duarte (I584-I653) to Constantijn Huygens written in Antwerp 2I November I640. This interesting letter by the Antwerp jeweler and music lover Duarte to Huygens was hidden in a private collection and unknown to Worp. The letter sheds light on the domestic music playing by the Duarte family and on the exchange of French and Italian affectations between Huygens and Duarte. Furthermore, it reveals that Duarte sent some medicine to the Stadtholder Frederick Henry through Huygens.

Regarding Constantijn Huygens's secretarial profession, even more letters have been recently discovered. For instance, 60 letters to and from the Frisian Stadtholder

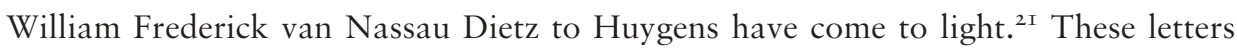
provide new insight on the friendship and gift-exchange between Constantijn and the Frisian Stadtholder. Though Constantijn did not belong to the Dutch nobility, as a secretary in the close vicinity of the Statholders and their spouses, he was a valuable relation and intermediary for William Frederick, who was constantly in need of favours from these souvereigns.

In addition, 50 letters from Constantijn to Amalia van Solms, most of them dated in the year 1646, have been found at the Landeshauptarchiv Sachsen-Anhalt, Dessau. $^{22}$ This collection fills the gap that has existed in the correspondence of 
Huygens and Amalia, the wife of his employer, Stadtholder Frederick Henry. ${ }^{23}$ These recently discovered writings of Huygens to Amalia expose new historical facts on the last year of the war campaign, supervised by Frederick Henry and assisted by his son William II. In detail, Huygens describes the activities and movements of the Dutch and allied French armies in Flanders and South-Limburg. Huygens's reports also shed new light on the negotiations in the run-up to the Peace of Westphalia in I648. Furthermore, the letters provide insight into how Huygens tried to keep both his employers (Frederick Henry as well as Amalia) satisfied. Frederick Henry died on I4 March I647. Already in I646, during the last war campaigns, his health had declined, he had moments of insanity, and was occasionally out of control. Huygens's eyewitness-reports to Amalia about how he and his entourage coped with Frederick Henry's illness and bad moods give us revealing and moving stories, heretofore unknown, on the last year of the life of the Dutch leader.

\section{The digital edition: new pespectives}

In spite of the criticism of Worp's work presented here, his contribution remains extremely valuable, as he accomplished the enormous task of inventorying the Huygens-correspondence and identifying thousands of persons mentioned in the letters. By taking Worp's edition as a starting point, the Huygens Institute of Dutch History is now creating a new digital edition, which is already online, and to which new material is frequently added. The old edition has been digitized and linked to a database, in which basic-data of the ro ooo letters of Constantijn Huygens have been added, such as date, location, name of correspondent, language, etcetera. Every letter has been or will be supplied with one or more facsimiles of the original documents and with the help of specialized Huygens scholars and volunteers the letters will be transcribed, annotated, and sometimes even translated. ${ }^{24}$ Consequently, due to the online availability of the original documents the researcher is no longer constrained by the limitations of the Worp-edition.

Drawing on the newly-digitalized sources, we have touched on the patronage system and gift exchange, the history of negotiations on the Princedom of Orange, the scientific world of Christiaan Huygens, and the biographies of major figures such as Charles II and Frederick Henry. Now we wish to present some new perspectives on different types of research. In what follows, we focus on the social stratification of the correspondents interacting with Huygens. We will also examine the langauge used in the letters. We will point to what the correspondence reveals about Constantijn's capacity as secretary; and finally we shall observe what the letter suggests about his attitude toward women.

\section{Correspondents}

We can distinguish between four categories of correspondents that were part of Constantijn's network. The first category are people evidently of much higher rank: statesmen, high nobility, queens, etcetera: for instance Queen Christina of Sweden, 
Cardinal Mazarin, Charles I and Charles II Stuart, and Louis XIV. Constantijn's rhetorical posturing vis-à-vis these individuals is rather submissive; his writings to them are verbose and full of rhetorical flourishes of respect. For example, Huygens finishes his letter to Elizabeth Stuart, Queen of Bohemia from 2 July I634 with: 'Je prie Dieu de bénir Vostre Majesté de Ses plus tendres bénédictions et celle de m'octroyer la grâce de me pouvoir qualifier. Madame' ('I pray God to bless Your Majesty with His most tender benedictions and that of granting me the grace to be able to promote myself, Madam'). ${ }^{25}$ Huygens kept precise copies or drafts of his letters to these people, as he did with the rarely received answers.

The second category consists of people of 'lower high-rank': gentry, city officials, regents, military officers, etcetera. Normally, Constantijn's correspondence with these people is on a professional level. Most of the letters he received from these individuals have been preserved; letters that Huygens wrote to them have hardly survived.

The third category are those persons who are Constantijns 'equals', the upper layer of the bourgeoisie and the under layer of the dominant class. Examples are his musical friend Utricia Ogle, the scholar Anna Maria van Schuurman, and the poet P.C. Hooft. Letters of this kind Huygens carefully kept amongst his personal papers.

The fourth category consists of individuals below Constantijn in social rank, people who looked up to him. Constantijn hardly saved any copies of his letters to this group of correspondents. In the few extant letters, we perceive a tone of reluctance. Some of the letters to Huygens by this rank of people, however, have been preserved. Letters from artists fall into this category; the collection, in fact, includes seven letters from Rembrandt to Constantijn.

\section{Languages}

Most of Constantijn's letters were composed in French or Latin, especially those directed to peers. Latin predominates in his correspondence with scholars and ministers, like Caspar Barlaeus, Nicolas Heinsius, and Anna Maria van Schuurman. He used the French language in his letters to the upper class in the Dutch Republic. Constantijn spent his whole life in a bilingual, Dutch-French, setting, as the Dutch court and the army were thoroughly under the influence of French language and culture. Equally, at his parental home Constantijn had been spoon-fed with the French language. According to Constantijn himself, at the age of two, he could recite the French version of the Ten Commandments by heart. His father had ordered his tutor Joannes Brouart to speak only French with Constantijn and his brothers. Constantijn reported:

Wij bereikten al binnen enkele maanden zo'n grote spreekvaardigheid in het Frans, dat wij aan het einde van het jaar die taal als vanzelf in de omgang gingen gebruiken. Dit wekte vooral verbazing bij de Fransen, in wier ogen wij in korte tijd dit moeilijke onderdeel hadden leren beheersen zonder dat wij hun land hadden bezocht.

[Within a few months we had reached such fluency in the French language, that we started to use the language commonly. Especially the French were surprised, as we had achieved this ambition without ever visiting their country. $]^{26}$ 
Constantijn seldom wrote in Dutch, except in correspondence with the Dutch poet P.C. Hooft. However, letters directed to Constantijn were often composed in Dutch, especially those written by 'ordinary people', such as the painter Rembrandt. Finally, there were small groups of letters composed in English, Italian, German, Spanish, and Greek.

\section{Constantijn as secretary}

The most important professional role in Huygens's life consisted of his work as secretary of the Stadtholder and as employee of the Nassause Domeinraad, an institution that administered the estates of the family of Orange. Huygens wrote a larger number of letters in this capacity than in any other. In the 20 years that Constantijn served Stadtholder Frederick Henry, the two had developed a confidential relationship. This was not the case with Frederick Henry's son and successor William II, who only reigned for two years. After William's sudden death in I650 Constantijn had a difficult time. He no longer had an Orange-Stadtholder as protector and he had to struggle to maintain his position. He managed to stay in the close circles of Amalia of Solms, widow of Stadtholder Frederick Henry and grandmother of William III, future Stadtholder and king of England. As a matter of fact, records show that Constantijn corresponded with Amalia more than with any other woman.

To be more precise, Huygens 834 letters to Amalia and 185 received from her have been preserved. ${ }^{27}$ His original letters to Amalia have been well kept, as he had asked one of her ladies in waiting to take good care of his letters and return them to him after Amalia's death, which she in fact did. Figure 2 shows some nice examples of the tiniest letters he wrote to Amalia. They have all been written during the war campaigns, in which he reported to her about the development of the war actions and the wellbeing of her husband Frederick Henry. These letters had to be smuggled through
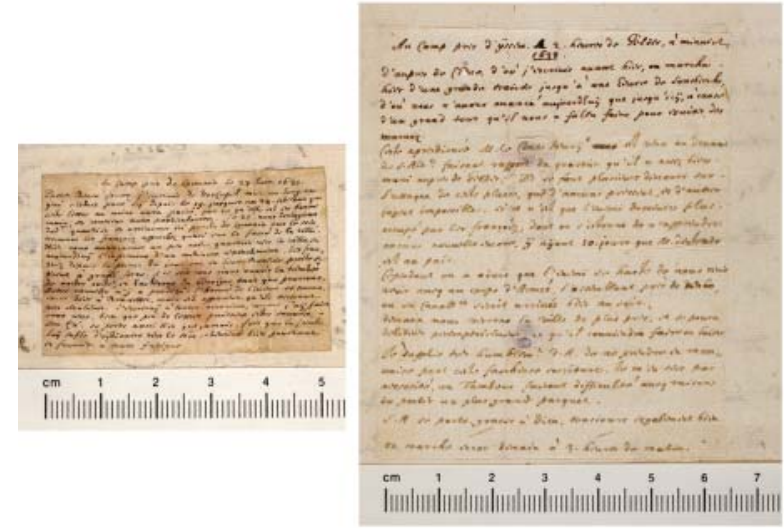

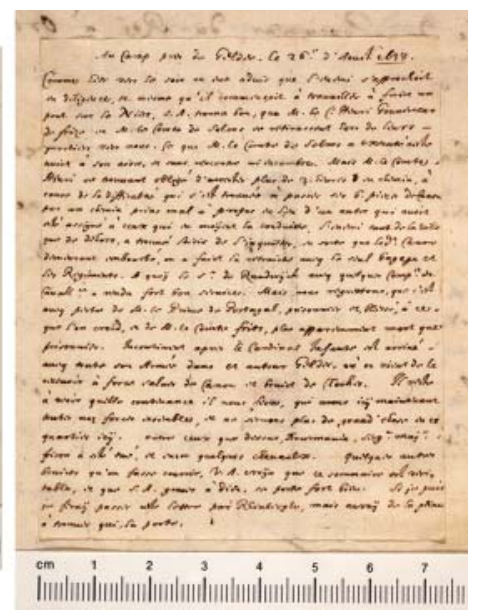

FIGURE 2 Letters from Constantijn Huygens to Amalia van Solms.

Royal Dutch Archive, The Hague, Archief Amalia van Solms, A14a-XIII-18c-1 
enemy lines in the boot of a soldier or through the air by a pigeon, and therefore they had to be extraordinarily small. Huygens must have written them with the help of a magnifying glass.

\section{Constantijn's contacts with women}

Constantijn's contacts with women have not been given much attention in historiography. Since his early childhood, Constantijn had a fascination with noble women. As a boy he was a welcome guest at the court of Louise de Coligny, widow of Stadtholder William I of Orange. Furthermore, in the twenties of the seventeenth century he frequented the exile court of Bohemian Queen, 'Winterqueen' Elizabeth Stuart in The Hague. In I624 Elizabeth had even used her influence to get Constantijn appointed as secretary of Stadtholder Frederick Henry. In return he rendered her his services, for example, breaking cipher codes and mediating in delicate matters. Constantijn also deeply admired Queen Christina of Sweden, to whom he sent his Pathodia Sacra et Profana together with a poem. He also kept intimate bonds with the ladies in waiting of the Winterqueen and of Amalia van Solms, in order to be completely informed about the conduct and of state of mind of their mistresses.

But besides his courtly contacts, he also maintained relationships with female scholars, poets, musicians, wives, and daughters of important male acquaintances. In fact, 20 per cent of Constantijn's currently known correspondence has been written with female acquaintances, a total of 185 different women. Figure 3 presents an overview of the total correspondence of Constantijn and the ratio of correspondence with men and women over the years. Table I demonstrates the top ro of women who most frequently corresponded with him.

Another remarkable relationship that Constantijn maintained was with the sisters Amalia and Treesje van Brederode, daughters of Wolfert van Brederode, fieldmarschal and first nobleman of Holland. The two ladies were respectively grandmistress and assistant-grandmistress of the Ordre de l'Union de la Joye, the Order of the Union of Joy. This society was inspired by the French salon and the salon of Béatrix de

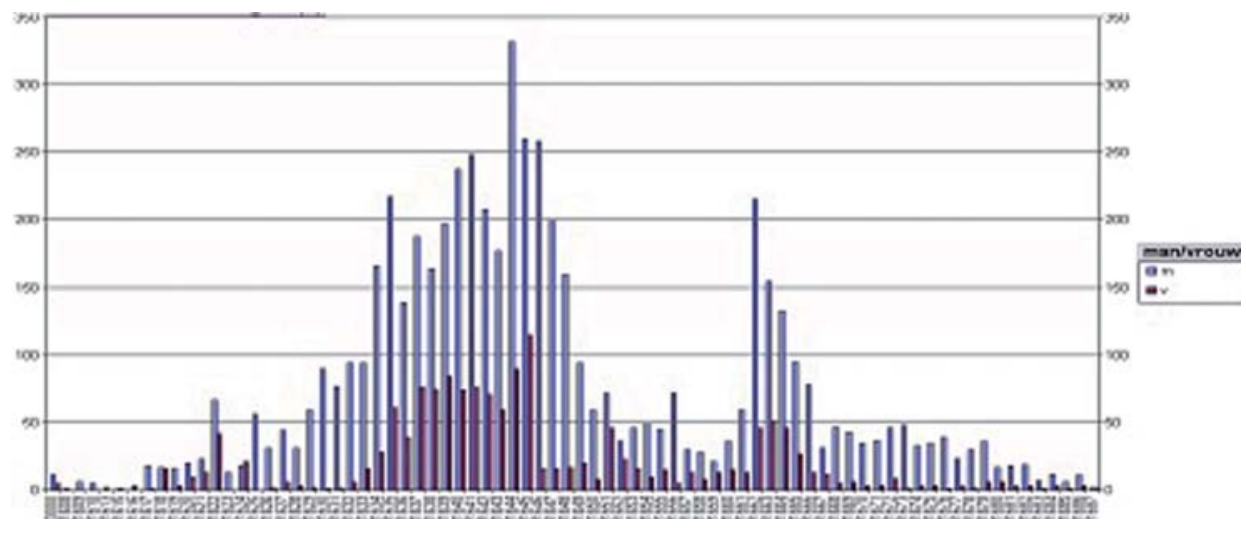

FIGURE 3 Total of letters to and from Constantijn Huygens over the years. 
TABLE 1

TOP 10 FEMALE CORRESPONDENTS WITH CONSTANTIJN HUYGENS

\begin{tabular}{ll}
\hline Total (to/from) & Correspondent \\
\hline $1019(834 / 185)$ & Amalia gravin van Solms-Braunfels, prinses van Oranje \\
$88(17 / 71)$ & Suzanna Huygens-Hoefnagel (Huygens's mother) \\
$68(45 / 23)$ & Béatrix de Cusance, hertogin van Lotharingen \\
$26(18 / 8)$ & Anna Maria van Schurman \\
$21(0 / 21)$ & Marie Lansame, douarière van Zomerghem \\
$19(19 / 0)$ & Utricia Ogle \\
$16(0 / 16)$ & Helena Liefferts \\
$14(1 / 13)$ & Emilia Secunda Antwerpiana, gravin van Nassau \\
$14(0 / 14)$ & Agnes Ploos van Amstel-van Bijler \\
$13(4 / 9)$ & Elisabeth von Loewenstein, hofdame van Elizabeth Stuart \\
\hline
\end{tabular}

Cusance, the Duchess of Lorrain, who was also an intimate friend of Constantijn. This Order of Joy which had chevaliers and chevalières, had its own regulations, medals, ceremonies, and diplomas. At the ceremony of admission, the candidates had to prove that they could laugh, dance, make fun, and hop like a sparrow. Huygens offered the grandmistress his services for the order as boy of the scullion ('valet du marmiton'). Only a month later Amélie promoted him to chevalier; which must have delighted Constantijn because now he could call himself equal amongst other members like raadpensionaris Johan de Witt, the Frisian Stadtholder William Frederick of Nassau Dietz, and even Queen Christina of Sweden, who was also a member. ${ }^{28}$

When people nowadays reflect on the scholarship of the Huygens family, most people think first of all of Christiaan, Constantijn's son. However, father Constantijn also carried out scientific experiments and he corresponded frequently with scholars, including female scholars like Anna Maria van Schuurman and Margaret Cavendish, the Marquise and later Duchess of Newcastle. Margaret and her husband William were royalist exiles who lived temporarily in the Netherlands. In I657 Huygens met Margaret in Antwerp and from then on the two kept in touch. Margaret was an extraordinary lady; she not only dressed outrageously, but she also wrote books, plays, and scientific treaties, activities considered unusual and even quite bizarre for a woman in those days. She was, therefore, nicknamed 'Mad Madge'. In I667 she was the first woman to be invited at the Royal Society in London. Huygens and Margaret corresponded, for instance, about 'Rupert's drops', a scientific curiosity created by dripping hot molten glass into cold water. Figure 4 represents a letter in which Margaret humbly thanks Constantijn for presenting her publications to the University Library of Leiden, where they can still be found. ${ }^{29}$

Constantijn met Margaret at the house of the Portuguese merchant family Duarte, the same place where a few years earlier he had met Béatrix de Cusance, the Duchess of Lorraine. With Béatrix he developed an intimate friendship. ${ }^{30}$ Huygens maintained a very good, perhaps even quite similar relationship with Béatrix's niece, Maria Elisabeth Princess of Hohenzollern, who was Marquise of Bergen op Zoom. Constantijn 


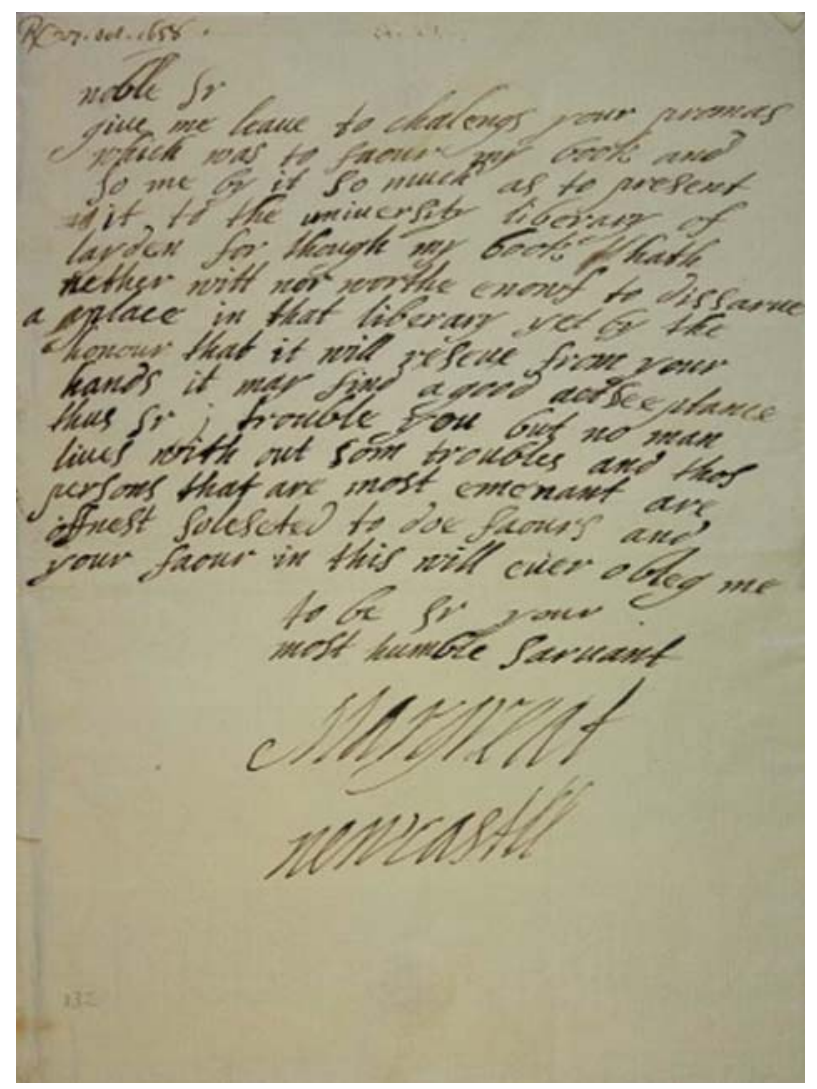

FIGURE 4 Letter from Margaret Cavendish to Constantijn Huygens.

Royal Dutch Archive The Hague, Archief Constantijn Huygens, G1-9.1

wrote quite daring poems for both ladies - comparing them both with Trijntje Cornelis, the protagonist from the burlesque with the same name, which he composed in I656. As Béatrix also had a claim on the Marquisate, the two ladies could not stand each other, and frequently Huygens found himself positioned in between the two fighting ladies. Nevertheless, he manoeuvred delicately and masterfully to stay in that very position. ${ }^{3 \mathrm{I}}$

\section{Conclusion}

As we have demonstrated, the new edition of the letters by, to, from, and about Constantijn Huygens is essential for modern research. The new edition expands the corpus edited by Worp and corrects his work where necessary. We do hope that we can count on volunteers for the transcription of the digitized letters we are currently providing. Step by step the edition of Huygens's Letters Online will then become an even richer source for all kinds of research regarding the Dutch Golden Age. The examples which have been given here show some of the important corrections and additions that the new editon has already provided. 


\section{Notes}

I http://resources.huygens.knaw.nl/briefwisselingcon stantijnhuygens.

2 Lise Gosseye, Frans Blom and Ad Leerintveld, eds. Return to Sender: Constantijn Huygens as a Man of Letters (Gent: Academia Press/Gingko, 2013).

3 Constantijn Huygens, Mijn leven verteld aan mijn kinderen in twee boeken, ed. by Fr. R. E. Blom (Amsterdam: Prometheus/Bert Bakker, 2003), pp. II92-94.

4 J. A. Worp, De briefwisseling van Constantijn Huygens (I608-I687), part I-6 (Den Haag: Rijkcommissie voor Vaderlandsche Geschiedenis, I9II-I9I7). Available from resources.huygens.knaw.nl/briefwis selingconstantijnhuygens. See: Ineke Huysman, 'Worp, Jacob Adolf (I85I-I9I7)', in Biografi sch Woordenboek van Nederland. Available from http://resources.huygens.knaw.nl/bwni880-2000/ lemmata/bwn6/worp.

5 Worp, De briefwisseling van Constantijn Huygens Part I, p. XXII.

6 See: http://resources.huygens.knaw.nl/briefwisseling constantijnhuygens $/$ brieven ?zk_correspondentid $=39$.

7 Worp, De briefwisseling van Constantijn Huygens Part I, p. XII.

8 Ibid, p. XIII.

9 See: http://resources.huygens.knaw.nl/briefwisseling constantijnhuygens/brief/nr/4883.

to Worp, De briefwisseling van Constantijn Huygens Part I, p. XIII.

${ }^{\text {II }}$ Ibid.

${ }^{12}$ See: http://resources.huygens.knaw.nl/briefwisseling constantijnhuygens/brief/nr/5592.

${ }^{13}$ M. Bax and N. Streekstra, 'Civil Rites. Ritual politeness in early modern Dutch letter-writing', Journal of Historical Pragmatics, 4 (2003), 303-25; Watts, R. J. 'Relevance and relational work: Linguistic politeness as politic behavior', Multilingua, 8 (I989), I3I-66.

${ }^{I 4}$ Constantijn Huygens, Nederlandse gedichten I6I41625. Historisch-kritische uitgave verzorgd door Ad Leerintveld (Den Haag, Constantijn Huygens Instituut, 200I), Part I, pp. 6-9; part 2, pp. 95-IO4.

${ }^{15}$ Leendert Strengholt, 'De oudste brief van Jacob Cats aan Huygens', in idem, Een lezer aan het woord. Studies van L. Strengholt over zeventiendeeeuwse Nederlandse letterkunde. Onder redactie van H. Duits (e. a.) (Amsterdam: Stichting Neerlandistiek VU; Münster: Nodus Publikationen, 1998), I23-30.

I6 Adriaan van der Weel and Peter Davidson, A Selection of the Poems of Sir Constantijn Huygens (I596-I687). A parallel tekst translated, with an introduction and appendices (Amsterdam: Amsterdam University Press, 1996), pp. 42-63.

${ }^{17}$ Worp, De briefwisseling van Constantijn Huygens, pp. $\mathrm{I} 77-78$.

${ }^{18}$ P. C. Hooft, 1976. De briefwisseling van Pieter Corneliszoon Hooft. Uitgegeven door H. W. van Tricht. Deel I. I599-I630. Culemborg: Tjeenk Willink/Noorduijn, 508-509.

${ }^{19}$ Huygens, Nederlandse gedichten, Part 2, pp. 4I-72; Leerintveld, Ad. 'Constantijn Huygens en de kopij voor zijn Otiorum libri sex'. Jaarboek voor Nederlandse Boekgeschiedenis, 9 (2002), 24-40 (pp. 25-40).

${ }^{20}$ Call number KW 79 E 235. See: http://resources. huygens.knaw.nl/briefwisselingconstantijnhuygens/ brief/nr/no293.

${ }^{2 I}$ See: http://resources.huygens.knaw.nl/briefwisseling constantijnhuygens/brieven?zk_correspondentid $=402$.

${ }^{22}$ See: http://resources.huygens.knaw.nl/briefwisseling constantijnhuygens/brieven?zk_correspondentid $=_{\mathrm{I} 2}$.

${ }^{23}$ See also p. II.

${ }^{24}$ See: http://resources.huygens.knaw.nl/briefwisseling constantijnhuygens.

${ }^{25}$ See: http://resources.huygens.knaw.nl/briefwisseling constantijnhuygens/brief/nr/952.

${ }^{26}$ Constantijn Huygens, Mijn Jeugd, ed. C. L. Heesakkers (Amsterdam: Querido, I987), p. 28.

27 See also p. 8.

${ }^{28}$ Ineke Huysman, 'Haagsche pretmakers uit de groote wereld: L'Ordre de l'Union de la Joye' omstreeks 1650', in Uit diverse bronnen gelicht: Opstellen aangeboden aan Hans Smit ter gelegenheid van zijn vijfenzestigste verjaardag, ed. by E. Dijkhof and M. van Gent (Den Haag: Instituut voor Nederlandse Geschiedenis, 2007), pp. I6I-82.

29 See also: http://extra.shu.ac.uk/emls/si-I4/akkecorp. html.

${ }^{\circ}$ Ineke Huysman and Rudolf Rasch. Béatrix en Constantijn. De briefwisseling tussen Béatrix de Cusance en Constantijn Huygens 1652-1662 (Amsterdam: Boom, 2009); Huysman, Ineke and Rudolf Rasch. The Friendship of Béatrix de Cusance en Constantijn Huygens', in Crossing Boundaries and Transforming Identities. New Perspectives in Netherlandic Studies, vol. 4, M. Bruijn-Lacy \& C. P. Sellin, eds. (Münster: Nodus Publikationen, 20I2), 3I-9.

${ }^{3}$ Nadine Akkerman and Ineke Huysman. 'Een zeventiende-eeuwse catfight: de geloofsovergang van Louise Hollandina van de Palts als inzet bij de aanspraken op het Markiezaat van Bergen op Zoom (I657-I659)', De Waterschans (Bergen op Zoom), 4I (2OII), 63-72. 


\section{Notes on contributors}

Ineke Huysman (I96I) works as a researcher at the Huygens Institute for the History of the Netherlands in The Hague in the Netherlands. She is currently working on an online edition of the correspondence of Constantijn Huygens, a seventeenth-century Dutch diplomat and poet. She is also writing a biography on Béatrix de Cusance, Dutchess of Lorraine (I6I4-63).

Correspondence to: Ineke Huysman, Huygens-Instituut voor Nederlandse Geschiedenis, Prins-Willem-Alexanderhof 5, NL-2595 BE Den Haag. Email: ineke.huysman@huygens.knaw.nl

Dr Ad Leerintveld (I952) is Keeper of Modern Manuscripts at the Koninklijke Bibliotheek, the National Library of the Netherlands, in The Hague. He studied Dutch Literature of the seventeenth century and Book History. His doctoral thesis is a historical critical edition of Constantijn Huygens's early Dutch poems. He publishes on Dutch seventeenth-century literature and culture, especially regarding Constantijn Huygens. He is President of the Hofwijck Society that recently has been able to restore (the remaining) part of Hofwijck, Huygens's estate that is now the Huygens Museum.

Correspondence to: Dr Ad Leerintveld, Koninklijke Bibliotheek, Prins-WillemAlexanderhof 5, NL-2595 BE Den Haag. Email: ad.leerintveld@kb.nl 